\title{
Leprosy Endemicity in Bombay: An Assessment Through Surveys of Municipal Schools*
}

\author{
R. GANAPATI, $\dagger$ S. S. NAIK, $¥$ M. Y. ACHAREKAR $\S$ AND S. S. PADE $₫$ \\ Acworth Leprosy Hospital, Wadala, Bombay 400 031, India
}

\begin{abstract}
Leprosy surveys of randomly selected municipal schools in Greater Bombay during 1970-71 revealed the existence of pockets where the endemicity was expected to be high (of the order of 10 per 1000). It became possible to identify these pockets, essentially located in the northern suburbs of the city, by arbitrarily grouping some schools in which a prevalence rate of more than 5 per 1000 was encountered.

This experience led to a second phase of intensive surveys of all the schools situated in 10 such endemic pockets. Results of these surveys form the subject of this presentation. Out of 83,413 children on the rolls, $67,857(81.4 \%)$ were available for examination, among which 733 leprosy cases could be identified. The overall prevalence rate of 10.8 per 1000 has confirmed our impression gained through previous surveys as regards the high endemicity in these localities.

In our opinion intensive surveys of schools located in presumably endemic zones should be given high priority in urban control programmes.
\end{abstract}

\section{Introduction}

The ample evidence available from the records of the Acworth Leprosy Hospital as regards the high endemicity of leprosy in Bombay, and the striking incidence of the disease among children of school age attending the leprosy clinics (Ganapati et al., 1971) prompted large scale leprosy surveys of municipal schools after making the selection of schools by random sampling (Ganapati et al., 1973). While the overall prevalence rate in schools in general was found to be 3 per 1000 we were struck by the existence of groups of schools where the prevalence was much higher than the general prevalence rate. The identification of 10 such "endemic spots", essentially located in the northern suburbs of the city (see map) was possible by arbitrarily grouping schools in which prevalence rates ranging between 5 and 17 per 1000 were encountered. Intensive surveys of all the schools situated

\footnotetext{
* Paper presented at the Seminar on Leprosy held by the Indian Association of Leprologists in Bombay on 29 November 1974.

$\dagger$ Present address: Medical Director, Greater Madras Leprosy Treatment and Health Education Scheme, 29/C Gajapathy Naidu Street, Shenoynagar, Madras 6000 30, S. India.

¥ Research Assistant.

$\S$ Assistant Medical Officer.

If Assistant Medical Officer.

Received for publication 21 August, 1975.
} 
in these localities were deemed necessary to confirm the impression of high endemicity in these areas. The results of these surveys, which were restricted to municipal schools, form the subject of this presentation.

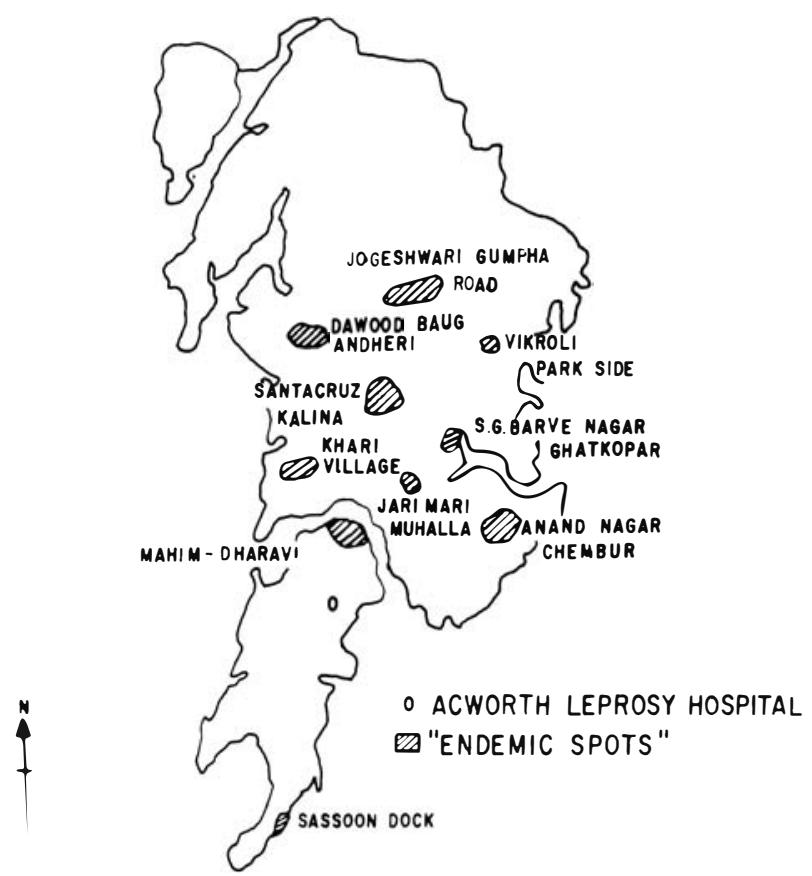

Fig. 1. Map of Greater Bombay showing "endemic spots" detected through school surveys.

\section{Material and Methods}

A total of 83,413 children were on the rolls in 148 schools situated in 10 presumably endemic localities. The operational methods of survey and technique of examination and case confirmation, etc. have been detailed in an earlier paper (Ganapati et al., 1973). As in the previous study, the presence of a BCG scar on the deltoid region was noted down, with a view to studying the relation, if any, between the scar and the occurrence of leprosy lesions. Facilities were provided to bring all the suspected as well as diagnosed cases to the clinic of the Acworth Leprosy Hospital for examination and confirmation by senior doctors. While $57.4 \%$ of the cases were confirmed in this way, the remaining were examined in the schools by senior workers and the diagnosis confirmed.

\section{Results and Discussion}

Table 1 shows the extent of coverage of students in the 10 groups of schools and the prevalence of leprosy in each group. 
TABLE 1

Area-wise distribution of cases

\begin{tabular}{|c|c|c|c|c|c|c|c|}
\hline No. & $\begin{array}{c}\text { Endemic } \\
\text { pockets }\end{array}$ & $\begin{array}{l}\text { No. of } \\
\text { students } \\
\text { on roll }\end{array}$ & $\begin{array}{l}\text { No. of } \\
\text { students } \\
\text { examined }\end{array}$ & $\begin{array}{c}\% \\
\text { covered }\end{array}$ & $\begin{array}{l}\text { Leprosy } \\
\text { cases }\end{array}$ & $\begin{array}{c}\text { Cases kept } \\
\text { under } \\
\text { observation }\end{array}$ & $\begin{array}{c}\text { Prevalence } \\
\text { rate } \\
\text { per } 1000\end{array}$ \\
\hline 1 & Mahim-Dharavi & 11891 & 9266 & 77.9 & 131 & 26 & 14.1 \\
\hline 2 & Khar-khari village & 7366 & 5897 & 80.0 & 84 & 9 & 14.3 \\
\hline 3 & Santa Cruz-Kalina & 17824 & 14794 & 83.0 & 215 & 35 & 14.5 \\
\hline 4 & $\begin{array}{l}\text { Andheri-Dawoodbag/Tata } \\
\text { compound }\end{array}$ & 9324 & 7566 & 81.0 & 88 & 16 & 11.6 \\
\hline 5 & Jogeswari-Gumpha Road & 13328 & 10418 & 78.2 & 120 & 16 & 11.5 \\
\hline 6 & Kurla-Jarimari Mohalla & 2442 & 1872 & 76.6 & 11 & 2 & 5.9 \\
\hline 7 & Chembur-Anandnagar & 974 & 745 & 76.6 & 9 & 1 & 12.2 \\
\hline 8 & $\begin{array}{l}\text { Ghatkopar-S. G. Barve } \\
\text { Nagar }\end{array}$ & 8087 & 6999 & 86.5 & 51 & 8 & 7.3 \\
\hline 9 & Vikhroli-Park side & 6717 & 5530 & 82.4 & 11 & 17 & 2.0 \\
\hline \multirow[t]{2}{*}{10} & Colaba-Sasson Dock & 5460 & 4770 & 87.3 & 13 & 12 & 2.7 \\
\hline & Total & 83413 & 67857 & 81.4 & 733 & 142 & 10.8 \\
\hline
\end{tabular}

Tables 2-4 show the distribution of cases according to age, sex, language groups, etc.

TABLE 2

Age distribution

\begin{tabular}{cccc}
\hline Age & Number examined & Leprosy cases & $\begin{array}{c}\text { Prevalence } \\
\text { rate per } 1000\end{array}$ \\
\hline $5-7$ & 18,555 & 157 & 8.4 \\
$8-10$ & 26,152 & 304 & 11.6 \\
$11-13$ & 16,956 & 193 & 11.4 \\
$14-16$ & 5,461 & 72 & 13.2 \\
$17-19$ & 682 & 7 & 10.3 \\
$20-22$ & 51 & - & - \\
Total & 67,857 & 733 & 10.8 \\
\hline
\end{tabular}

TABLE 3

Sex distribution

\begin{tabular}{lccc}
\hline \multicolumn{1}{c}{ Sex } & Number examined & Leprosy cases & $\begin{array}{c}\text { Prevalence } \\
\text { rate per 1000 }\end{array}$ \\
\hline Male & 36,943 & 453 & 12.3 \\
Female & 30,914 & 280 & 9.1 \\
Total & 67,857 & 733 & 10.8 \\
\hline
\end{tabular}


TABLE 4

Distribution according to language groups

\begin{tabular}{lcccc}
\hline Language & $\begin{array}{c}\text { Number of } \\
\text { students examined }\end{array}$ & $\begin{array}{c}\text { Cases kept under } \\
\text { observation }\end{array}$ & $\begin{array}{c}\text { Leprosy } \\
\text { cases }\end{array}$ & $\begin{array}{c}\text { Prevalance rate } \\
\text { per } 1000\end{array}$ \\
\hline Marathi & 40,109 & 82 & 453 & 11.2 \\
Tamil & 1,607 & 5 & 24 & 14.9 \\
Gujarati & 5,514 & 7 & 43 & 7.8 \\
Telugu & 525 & 2 & 3 & 5.7 \\
Hindi & 7,770 & 19 & 77 & 9.9 \\
Urudu & 9,024 & 17 & 86 & - \\
Sindhi & 14 & 0 & 4 & 6.2 \\
English & 645 & 7 & 42 & 15.8 \\
Kannada & 2,649 & 142 & 733 & 10.8 \\
Total & 67,857 & & &
\end{tabular}

These surveys have revealed an overall prevalance rate of 10.8 per 1000 in the groups of schools situated in the areas referred to and this conforms with the impression gained through our earlier surveys as regards the high endemicity in these localities. Bechelli et al. (1973) have correlated the prevalence rates in children and in the total population obtained from studies from various parts of the world and have concluded that the rate found among children 5-14 years old usually reflects the degree of endemicity for planning purposes, as it is easier and less costly to examine school children than other groups. Recent observations in Bombay (Ganapati et al., 1975) from a total population survey of a large closed colony, as well as a survey of schools situated in the same colony, have confirmed the usefulness of such a procedure

The findings of lesser prevalence in the 5-7 year age group as opposed to the maximum prevalence in 14-16 year group (statistically significant: $\chi^{2}=10.06$; $P<0.005)$ and the higher prevalence among male children are similar to our observations in the earlier surveys. As regards the prevalence among various linguistic groups, rates of more than 10 per 1000 were encountered among Marathi, Tamil and Kannada speaking children, Marathi being significantly different from Kannada $\left(\chi^{2}=4.5, P<0.05\right)$.

Table 5 shows the relation between the presence or absence of BCG vaccination marks and the number of leprosy cases detected.

As in our previous study, the number of cases in the BCG vaccinated group is less than that in the non-vaccinated group; but unlike our earlier finding, this difference in incidence is highly significant $\left(\chi^{2}=22.8\right.$ with $\left.P<0.01\right)$.

TABLE 5

Relation between BCG scars and cases detected

\begin{tabular}{lccc}
\hline $\begin{array}{c}\text { BCG vaccination } \\
\text { scar }\end{array}$ & $\begin{array}{c}\text { Number of } \\
\text { students examined }\end{array}$ & $\begin{array}{c}\text { Number of } \\
\text { leprosy cases }\end{array}$ & $\begin{array}{c}\text { Prevalence rate } \\
\text { per } 1000\end{array}$ \\
\hline Present & 37,669 & 343 & 9.0 \\
Not present & 30,188 & 390 & 12.80 \\
Total & 67,857 & 733 & 10.80 \\
\hline
\end{tabular}


It was however not possible to obtain data on the vaccination and its relation to the occurrence of lesions, etc.

Out of 733 cases, 715 belonged to the non-lepromatous type. Of the 18 suspected infectious cases 12 could be confirmed to be smear positive by bacteriological examination, the remaining not being available for confirmation. A detailed analysis of the clinical features of these cases will form the subject matter of a future presentation.

The results of this investigation have strengthened our belief that intensive survey of schools located in presumably endemic zones should be given high priority in urban control programmes.

It is suggested that this technique of judging the general prevalence rates through detection of endemic foci after random sample surveys of child population should be applied especially in urban areas where whole population surveys cannot be done easily.

\section{Acknowled sement}

We thank the Superintendent of the Acworth Leprosy Hospital for permitting us to carry out these surveys and allowing us to publish this article.

We are also indebted to the medical and non-medical staff of the Acworth Leprosy Hospital for their cooperation in conducting the surveys.

\section{References}

Bechelli, L. M., Garbajosa, P. G., Gyi, M. M., Uemura, K., Sundaresan, T., Tamondong, C., Domingues, V. M., Sansarricq, H. and Walter, J. (1973). Proposed method for estimating leprosy prevalence based on rates in children. Bull. Wld Hlth Org. 48, 502.

Ganapati, R., Parikh, A. C. and Sane, A. B. (1971). Prevalence of leprosy among children in Greater Bombay. Pediat. Clin. India 6, 13.

Ganapati, R., Naik, S. S., Sane, A. B. and Parikh, A. C. (1973). Leprosy among children in Greater Bombay-Results of surveys. Lepr. India 45, 151.

Ganapati, R., Naik, S. S., Pandya, S. S., D’Souza, N. G. A. and Dongre, V. V. (1975). Unpublished observations. 